\section{Book}

Review

Access this article online

\section{Website:}

http://ajobe.journals.ac.za/

DOI:

$* * *$

Quick Response Code:

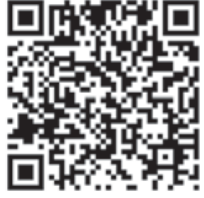

\title{
Theory and Practice of Government
}

Accounting in Nigeria

Reviewer: Kabiru I. Dandago

Authors: Professor Eddy Olajide Omolehinwa and Mr. James Kayode Naiyeju, JP, OON

Publisher: Pumark Nigeria Limited, Ipaja Road, Agege, Lagos

Date of Publication: August 2011

Venue: Shehu Musa Yar'adua Conference Centre, Abuja

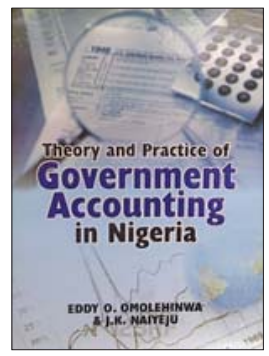

\section{INTRODUCTION}

Accounting is widely accepted as the process of identifying, measuring, and communicating economic information to enable informed judgments and decisions by users of the communicated information. The users of an organization's accounting information are both internal and external, with diverse accounting information needs for various decisions to be taken. These users could be identified in the private, public, and non-governmental organisation (NGO) sectors of an economy. Public accounting decisions influence government departments and, consequently, an economy as a whole.

While scholars and practitioners, as well as their institutes, pay a great deal of attention to private sector accounting, public sector (government) accounting does not receive the attention it deserves. Most publications by accountancy scholars and practitioners, especially in developing economies like Nigeria, address financial accounting or management accounting in the private sector. Public sector accounting, however, has received little attention from authors in the field.

In Nigerian universities and polytechnics that offer accounting programmes as part of a Higher National Diploma, B.Sc or M.Sc qualifications, one hardly encounters more than one course unit on government accounting, usually a mere one-semester course. Furthermore, few M.Sc. and PhD candidates conduct research on topics related to government accounting.

At the professional level, both the Institute of Chartered Accountants of Nigeria (ICAN) and the Association of National Accountants of Nigeria (ANAN), the two recognized accountancy professional bodies in Nigeria, include only one paper in their qualifying examinations to test the knowledge of their students on government accounting.

In response to these shortcomings in the theory and practice of public sector accounting, Eddy O. Omolehinwa of the University of Lagos and J. K. Naiyeju, JP, OON, a former Accountant General of the Federation, pooled their reservoirs of theoretical and practical knowledge of government accounting to write a book that could guide tertiary education institutions in redesigning their accounting curricula. The book contains 19 chapters, each with a solid introduction, clear conceptual explanations, practical and critical thoughts, and lucid concluding remarks. Each chapter also contains practice questions for readers to test their understanding of the contents. A chapter-by-chapter analysis of the book is provided below.

\section{SYNTHESIS OF THE BOOK CHAPTERS}

Chapter One is an overview of accounting in the public sector. The chapter discusses the nature of government accounting, especially in Nigeria, the role of government in society, the 'virgin' areas of research in public sector accounting, and the problems in conducting research on government accounting in Nigeria and beyond. The chapter also describes the nature of non-profit organizations and how they differ from profit-orientated organizations. It concludes by encouraging persons interested in doing research on government accounting in Nigeria to seize the opportunities provided by the ongoing reform in governmental financial management, especially the enactment of the Fiscal Responsibility Act (FRA) of 2007.

Chapter Two traces the sources of government accounting practices and standards in Nigeria. It reviews the major provisions of the 1999 Constitution of the Federal Republic of 
Nigeria relevant to government accounting, the provisions of the Finance Control and Management Act of 1958 (now Cap f26 LFN 2004), the Public Procurement Act of 2007 (PPA), the FRA, the Nigerian Sovereign Investment Authority Act of 2011, the International Public Sector Accounting Standards Board and its standards, the International Auditing and Assurance Standards Board and its standards, and the standardized reporting format for the three tiers of government in Nigeria, as approved by the Federation Account Allocation Committee.

Chapter Three discusses financial control under the Fiscal Responsibility Act (FRA), which is arguably the second most important law since the 1999 Constitution of the Federal Republic of Nigeria. The law provides for effective budgeting and budgetary control, effective revenue sourcing and generation, debt management, and expenditure control, emphasizing the need for prudence, transparency, and accountability as cornerstones of responsible accounting.

Chapter Four highlights the roles of the financial officers of government. The chapter clarifies the institutes and role players involved in government accounting in Nigeria, including the president, the national assembly, the Minister of Finance, the Budget Office of the Federation, etcetera. More specifically, the functions of the Minister of Finance, the Accountant General of the Federation, the Auditor General for the Federation, treasury accountants (directors of finance and accounts), internal auditors, accounting officers, sub-accounting officers, revenue collectors, and imprest holders are emphasized and explained.

Chapter Five includes the specific roles of key institutions and role players, other than financial officers, in government accounting. In particular, the chapter discusses the roles of the president and the national assembly in government budgeting, as well as the roles of: (i) the Budget Office of the Federation, (ii) the central bank of Nigeria, (iii) the Fiscal Responsibility Commission, and (iv) the Bureau of Public Procurement.

Chapter Six trails government experimentation with accrual accounting in the West. The chapter offers reasons why there is an attempt to move from the cash basis of accounting to an accrual basis in some countries, and explains the benefits of an accrual accounting system in government in the United Kingdom. The experience of the New Zealand government with accrual accounting and an overview of the impact of this on government accounting practices is also reviewed. The chapter ends with the question whether governments of developing countries should embrace an accrual accounting system or not.

Chapter Seven focuses on government budgeting from a historical perspective. It commences with a discussion on the origin of a national budget, emphasizing that it is the most important instrument in managing the scarcity of resources. The concept of incremental budgeting, its criticisms, and efforts made to reform government budgeting away from incrementalism are also included. The Planning-Programming-Budgeting System (PPBS), zero-based budgeting (ZBB), the Government Performance and Result Act (GPRA), and Resource Accounting and Budgeting (RAB) as techniques/systems of budgeting are explained in terms of their origins, implementation procedures, advantages, and disadvantages as experienced in the USA and the UK.

Chapter Eight begins with a theorem by O'Rourke (1947) that, "When politics are used to allocate resources, the resources all end up being allocated to politics." The chapter provides an explanation of government budgeting and its purposes. It presents the relationship between Vision 20:2020, the medium-term expenditure framework and the annual budget, the steps involved in government budgeting, and the stages of federal government budget formulation and authorization.

Chapter Nine addresses the implementation, monitoring, and evaluation of government budgets. As budget implementation is a crucial issue in Nigeria, the chapter reviews all the sections of the FRA 2007 governing the implementation of budgets. It discusses the concepts and purposes of warrants and authority to incur expenditure, objectives of budget monitoring and evaluation, and the agencies involved in monitoring and evaluating budgets at federal government level. This chapter is also a useful guide to encouraging public expenditure tracking and whistle blowing.

Chapter Ten is titled: "Towards effective capital project implementation." It reviews the characteristics of effective budgeting, as envisaged by the FRA, a number of basic factors required for effective capital project implementation, capital budget implementation problems in the past (focusing on the period 1977-1994), and recent capital budget implementation challenges.

Chapter Eleven is concerned with revenue sources and the allocation of government revenues. It explains the concepts of the federation account and its revenue sources (oil and non-oil), the independent sources of revenue for federal government, and the agencies responsible for collecting these revenues, and the role of the Revenue Mobilization, Allocation and Fiscal Commission. Bases of revenue allocation from the federation account and the differences between the federation account and the consolidated revenue fund of federal government are also presented.

Chapter Twelve addresses the concepts of cash planning and a cash management system at federal government level. The objectives and characteristics of effective cash planning 
and management are described, and the laws guiding the cash management system in Nigeria are highlighted. The chapter also reviews the procedures for revenue collection by the Nigerian National Petroleum Corporation, Department Petroleum Resources, Federal Inland Revenue Service, and the Nigeria Customs Service.

Chapter Thirteen focuses on special accounts of government, such as the $7 \%$ port development surcharge, the sugar development levy, the $5 \%$ rice development levy, the cocoa development levy, the $2 \%$ Education Trust Fund (now known as the TET Fund), the signature bonus account, etc. The chapter describes 15 such accounts. The chapter suggests that the major justification for these accounts is that they are intended as quick interventions for speedy development of specific sectors of the economy, such as education and the cultivation of sugar and rice.

Chapter Fourteen discusses the Federal Government of Nigeria (FGN) procurement contracts, addressing the provisions of the Public Procurement Act (PPA) 2007. The concept of procurement and the road to the PPA are examined. The chapter provides a critique of the award of contracts for cement importation by the Ministry of Defence without due regards to budgetary appropriation. The chapter further discusses procurement issues such as the fundamental principles of procurement at the federal government level, the function of the National Council on Public Procurement, the role of the Bureau of Public Procurement, the Tenders Board, payments for contracts, payment for mobilization fees, as well as offences and sanctions under the PPA.

Chapter Fifteen is titled: "Public borrowing and debt management in Nigeria." It describes the role of the Debt Management Office (DMO) and its powers and functions, and discusses the regulations governing government borrowing in Nigeria, especially bank lending to government institutions. The chapter shows the provisions of the FRA 2007 as contributing substantially to the legal framework of the DMO.

Chapter Sixteen addresses reform of the Nigerian government's financial reporting system. It discusses the reporting requirements of MDAs to the Office of Accountant-General of the Federation, the E-payment system (meaning, objectives, benefits, tools, and challenges), the Government Integrated Financial Management Information (GIFMIS) system, the Accounting Transactions Recording and Reporting System (ATRRS), and the Integrated Payroll and Personnel Information System (IPPIS).

Chapter Seventeen analyses government financial reporting in Nigeria. It starts by discussing the factors that brought about improvement in the usefulness and timeliness of the Accountant General of the Federation's reports and the essential information contained in the FGN's financial statements. The chapter also discusses gaps identified by the World Bank in the FGN's financial reporting (p. 261) and Wynne et al.'s (2008) identification of good practices in Nigerian financial reporting (p. 262). The chapter concludes with the suggestion that, while it is good to think globally in the area of financial reporting, Nigeria must not lose its focus on acting locally to address local challenges.

Chapter Eighteen focuses on public accountability in Nigeria. The chapter addresses the principles of public accountability, the IMF Code of Good Practice on Fiscal Transparency, the conditions that promote public accountability, and provides an overview of public accountability in Nigeria (1960 to 1999).

Chapter Nineteen addresses the thorny issue of a sovereign wealth fund (SWF). James Freeman Clarke (1810-1888) is quoted as saying: "A politician thinks of the next election; a statesman, of the next generation." This is food for thought for Nigeria, as it appears as if the country is increasingly producing politicians rather than developing statesmen. Effective wealth management at all levels demands investment for future generations rather than spending everything to satisfy the present generation. The chapter also examines the different types of sovereign wealth funds, as well as how an SWF differs from a foreign exchange reserve.

\section{AREAS OF IMPROVEMENT IN THE BOOK}

I want to draw the attention of the authors to some areas of the book that could be improved, should they consider producing a second edition. In some of the chapters, it is assumed that readers have background knowledge of the subject matters addressed, as conceptual explanations of key terms are not offered. For example, the discussion on International Public Sector Accounting Standards in Chapter two does not adequately create an appreciation in readers of the importance of those international standards, whose versions are not available at the local (Nigerian) level.

In Chapter 10, it is assumed that readers can correctly define a capital project, a capital budget, and budget/project implementation, and that they know the difference(s) between a capital budget and a capital project. While the chapter addresses effective capital project implementation issues (especially as provided in the FRA 2007), the two practice questions at the end of the chapter are on government budgeting generally.

Another example of the sweeping assumptions of the book is the treatment of public debt in Chapter 15, where it is assumed that readers have background knowledge of the meaning of public debt, the differences between 
internal and external public debts, the causes, benefits, and consequences of public debt (internal and external), as well as the strategies for managing public debt.

Only Chapters $3,5,7,11,12$, and 16 carry reviewed essay questions with suggested answers. All of the other 13 chapters should have been provided with such guiding questions and answers for improved self-assessment of the reader's understanding of the subject matters.

\section{RECOMMENDATIONS}

This is the latest book on government accounting in Nigeria, and it addresses practical rather than theoretical government budgeting, accounting, financial management, financial reporting, and government auditing issues in 19 chapters. This book was authored by a thoroughly established scholar and a highly successful practitioner, and students of accounting at the academic and professional levels should be satisfied that a solution to the government accounting problem is captured in this book. The book is a 'must read' for all students enrolled for government/ public sector accounting courses at Nigerian universities, polytechnics, ICAN, ANAN, and any other relevant accounting examining institution.

The contents of the book should serve as a guide to overhauling the syllabi of tertiary education institutions offering programmes in accounting, and also informs accountancy professional bodies in the areas of government accounting and public finance. This overhauling and restructuring of syllabi may lead to the creation of more course units on public sector accounting and public finance in accounting programmes and more exams on public sector accounting and public finance.

There is no publication that simplifies and promotes the provisions of the FRA 2007 and the PPA 2007 like this book; it might just as well have been sponsored by the Fiscal Responsibility Commission or the Bureau for
Public Procurement. The two federal government agencies should embrace this book and encourage ownership and intimate understanding of the contents by all ministries, departments and agents, (MDAs), corporate entities, and individuals with whom they do business.

The office of the Accountant General of the Federation and the Auditor General for the Federation should ensure that copies of this book are obtained, and the contents intimately understood, by all MDAs of the federal government.

Civil society organizations, organized labor, the Academic Staff Union of Universities, and other, similar unions/ associations could accept the book as a useful guide to their whistle blowing efforts in running government business in Nigeria. The book contains many facts and figures that could be used to promote prudence, probity, transparency, accountability, competitiveness, and sincerity of purpose in public governance in the country.

As the book is skewed towards federal government accounting and finance, there is an urgent need for the two authors to consider producing a publication that specifically addresses: (i) state government accounting and finance, (ii) local government accounting and finance, and (iii) NGO accounting and finance.

\section{CONCLUSION}

It is my wish that the book be well received by the target audiences, and that it will serve as the long-awaited agent of positive and progressive change in the field of public sector accounting and finance, as well as ethical accountability, in Nigeria and beyond.

Kabiru I. Dandago

Professor of Accounting and Chair, Bayero Consultancy Services Unit, Bayero University, Kano-Nigeria. E-mail: kidandago@gmail.com

\title{
AUTHOR
}

Kabiru I. Dandago, Professor of Accounting and Chair, Bayero Consultancy Services Unit, Bayero University, Kano-Nigeria.

\begin{abstract}
Announcement
Android App
\end{abstract}


Reproduced with permission of the copyright owner. Further reproduction prohibited without permission. 